\title{
Overcoming Greed: Buddhists and Christians in Consumerist Society
}

\author{
Paul F. Knitter \\ Xavier University
}

As I understand my assignment, I don't find it an easy one. I've been instructed to carry on a lopsided dialogue. Generally, what generates productive dialogue is a proper balance of learning and questioning. My assigned job in this exchange is to question more than learn-to offer some Christian queries about how Buddhists think we can overcome greed and find a path out of the consumerist jungle that surrounds us. Actually, I'd prefer it the other way around, for I'm convinced that we Christians have some very important, if not absolutely vital, things to learn from Buddhists in our own efforts to deal with the jungle. And I will mention some of them. But, following instructions, my main focus in what follows will be on areas where I suspect that Buddhists can learn something, maybe something very helpful, in our shared efforts to deal with greed and the havoc it is working on people and planet.

I need to specify my Christian voice in this conversation-or, as they say, where I'm coming from within the many and diverse neighborhoods that make up the Christian community. I'll be reflecting and speaking out of my knowledge of and experience with Christian liberation theology, especially as it has been born, developed, and taken new shapes among the poor and suffering of Latin America. The voices and concerns you will hear in my own remarks are originally those of Christian thinkers and activists such as Jon Sobrino, Gustavo Gutiérrez, Leonardo Boff.

In order to bring some order into the swarm of insights and questions that these extremely rich presentations have stirred up in me, I'll gather my comments around two broad topics.

\section{THE INNER AND THE OUTER: ENLIGHTENMENT AND THE REIGN OF GOD}

My first general area of conversation is a familiar one not just for the BuddhistChristian conversation but also for all activists who call themselves religious: the need for, but the difficulty of, holding together the "inner and the outer"-action and 
contemplation, personal and social transformation, or what I will term Buddha's enlightenment and Jesus' vision of the Reign of God.

\section{What Christian Liberation Theologians Need to Hear from Buddhists}

First, let me simply list, and hold back from delving into, some crucial lessons that we Christians not only can but drastically need to learn.

First, what Jesus and his followers call the Reign of God will be built on sand unless it is grounded in the personal, inner conversion of those who are trying to build it. The church will be only a empty building — or worse, a den of thieves — if its members, and that includes its leaders, are not transformed by the Spirit. Or, in Judith Simmer-Brown's words, "No fundamental transformation can take place anywhere without the joining of inner change and outer change" (emphasis mine). Or, in Ken Barnhill's words (quoted by Brown), "Social work entails inner work. . . . social change and inner change are inseparable." Or, in the powerful and widely quoted admonition of Thich Nhat Hanh: We have to be peace if we want to make peace. Christians know this, and they talk about it. But in my own life and in what I see in my church, how often we forget it in our efforts to get things done, in our concern for the institution, in our determination to bring about political change.

Second, I both cringed and nodded approvingly when I read about Judith Simmer-Brown speaking about "idiot compassion." In opposing wealthy landowners in El Salvador, or in a business-controlled city council in Cincinnati, how often I have felt but perhaps not identified in myself and in my fellow Christian activists "... unskillful acts . . . the impulsive response based on insufficient knowledge [that] can quickly become ineffective, causing personal burnout." Such idiocy, grounded in goodwill, derives, again, from an insufficient balancing of the inner and the outer.

Third, and more sharply focused on the suffering caused by greed, Judith offers a hope, or deep belief, that is often not clearly present among liberation theologians since the demise of the Soviet Union and the mighty rising of "neoliberalismo" or globalization. Since the early 1990s I've often heard people in El Salvador say "Era mejor cuando era peor" ("It was better when it was worse"), that is, it was easier then to struggle against the "Fourteen Families" and their military might than it is now against the dispersed, nonlocalized, supernational power of the global market. To really believe, however, in the conditioned, transient nature of all reality, Judith tells us, is also to believe that everything, even the established, amorphous workings of neoliberal economic structures, can be changed. We therefore can have, as we must have, "the confidence that no phenomenon is evil, flawed, or resistant to influence on an absolute level. . . . no problem of human life is intractable." In the face of the kind of empire we are dealing with today, such confidence is essential.

\section{Structural Greed and Personal Greed: Theyre Really Different}

I know this is an oft-discussed issue; but I also suspect that it is sometimes resolved a little too facilely on the Buddhist side (though that is not their intention). While 
Buddhists in general will certainly distinguish between social structures and personal perceptions, they seem to subordinate the structural to the personal too broadly. In our present discussion, Judith Simmer-Brown and David Barnhill clearly mark the differences between inner and outer causes of greed and insist on the need for a "Buddhist analysis of reality beyond the psychological and the metaphysical to the social, structural dimension of life," (David). But I also suspect that both of them share the assumption that the inner or personal causes and conditions are the determinative and sustaining source of the outer or structural realities.

Judith Simmer-Brown reminds us, for instance, that for the Buddha, "The root of all evils ... was a mistaken view about the nature of reality. He remained unconfused concerning his central insight, that these social issues cannot be changed without a concerted focus of understanding of this root." Then she goes on to suggest (only a suggestion, I admit) that to change this "mistaken view" will necessarily, though partially, change the "social issues": ". . . every single act of clear seeing or compassionate wisdom reverses in some small way one's ignorance concerning the basic nature of reality. At the same time all of these actions change in some small way the entire international phenomenon of globalization."

As a Christian liberation theologian I would agree; but I would immediately want to warn that it is not enough. Liberation theology, I believe, pushes the distinction between the personal and the social even further; the two are not only distinct, they are separate. Although the structures of greed found in economic, social, and political realities all stem from inner ignorance and desire, once these structures take shape, they have an existence and independence of their own. Like a child born of his/her parents, once the structures of business practices, political policies, and international organizations (such as the WTO) are born of the greed-rooted-in-ignorance of human hearts, they assume a reality of their own. Identifying the parent, one still has to deal with the child.

Therefore to change the inner state of people will not necessarily lead to a change of outer realities. Yes, being peace may be necessary for making peace, but being peace, by itself, will not automatically make peace in society. Yes, we need changed hearts to change the system, but changing our hearts is not enough to change the system. Inner change is a necessary requirement, but not a sufficient requirement, for outer change. This, I believe, is what lurks behind the reality of what David Barnhill describes as our almost unavoidable complicity in the greed that saturates the very cultural air we breathe. Even with our changed hearts, the structures suck us in and make us part of their functioning.

So something else is needed besides our change of heart or besides our personal enlightenment and transformed consciousness. In order to bring about a change in the structures of greed that have resulted from our ignorance but have taken on a life of their own, we need not just a prajna that will reveal the workings of our mind but also a prajna that enlighten the workings of global economics and politics. Furthermore, as a result of this social enlightenment and analysis, we must engage in active, organized resistance, political action, and, yes, perhaps even revolution that will bring about structural change. 
What I'm trying to get at is contained, I believe, in some basic symbols and principles of Christian liberation theology.

\section{The Reign of God and the Need for Structural Change}

One of the few things that scholars and searchers for "the historical Jesus" can agree on is that the burning heart of Jesus' message and mission was the Basileia tou Theou - the Reign of God. Jesus came to announce not just God but the Reign of God; God without the Reign was for him a false God. This God that Jesus experienced and announced, therefore, was up to something in this world. There was, one could say, a thorough nonduality between God and God's kingdom. To know and feel this God was, inherently, a matter of both converting the heart and converting the world. The more the followers of Jesus were transformed by Jesus' Spirit, the more they would transform society into a community of mutuality and justice. Inherent in the religious experience of Christians is the call to transform social structures.

That structural change of society is integral to Christian spirituality is evident in the primary recipients of the Reign of God: the poor. As liberation theologians put it, Jesus, and therefore the God of Jesus, has a preferential option for the poor-that is, for those who have been pushed aside, taken advantage of, exploited, oppressed, victimized. Indeed, God's love is universal, all-inclusive; but it is also, for Christians, preferential. As parents naturally show a particular concern for those of their children who are suffering, so too does God. Asian liberation theologian Aloysius Pieris suggests that if Christians are going to talk about the uniqueness of Christ in a manner that is both faithful to the witness of the New Testament and responsive to the needs of our world, here it is: Jesus embodies "Yahweh's defense pact with the poor." 1

Pieris uses the image of a defense pact to make clear that there are forces in this world that must be opposed, overcome, changed-or, in the terms of Jon Sobrino of El Salvador, the Kingdom of God confronts the "anti-Kingdom" of the powers. ${ }^{2}$ As the Kingdom of God is a socially structured reality, so too is this anti-Kingdom. Greed, in other words, is not just the result of ignorance. It is also idolatry. As an idol of stone stands in front of you and can block your path, so too does greed take rock-hard shape in the economic and political practices and laws. Such structures seek to usurp the very place and power of God. Therefore they must be resisted and removed from the temple of God's creation.

I know there are dangers in speaking about an "anti-Kingdom" that must be resisted and removed. Thich Nhat Hanh is not at all wasting words when he warns liberation theologians of the pitfalls of "taking sides." 3 Christians need all the help they can get from Buddhists in learning how to stand with the oppressed without standing against the oppressors - that is, how to prefer the struggling poor without hating the exploiting rich. Yet some kind of active resistance, and active social reconstruction, is necessary. The Kingdom of God requires both the transformation of the heart and the transformation of society. As nondual realities, both transformations inhere in each other, but they cannot be reduced to each other. 


\section{Justice and the Reign of God}

I suspect that the difference I am trying to identify between Buddhist and Christian spirituality regarding structural change has to do with the centrality of justice in the Reign of God. If Buddhists do seek to change the world, they seem to go about it somewhat differently than do Christians. Perhaps I can get at this difference in this overly simple sketch of the steps that Buddhists and Christians take in seeking to change the world:

- Buddhists move from: wisdom (enlightenment) $\rightarrow$ compassion $\rightarrow$ change in the world.

- Christians move from: "Being in Christ" (as Paul describes Christian life) $\rightarrow$ compassion $\rightarrow$ justice $\rightarrow$ change in the world.

Christian liberation theologians would make the explicit insertion of justice into the movement from personal spiritual transformation to transformation of society. To ensure that compassion will lead to the kind of structural change that will bring the world closer to the Reign of God, one must consciously speak about and work toward justice. The Christian concern for justice gives a further content, or directionality, to compassion. We're not talking about retributive justice but distributive justice: something must be done in the way the business of the world is conducted in order to bring about a more equitable distribution of the world's goods. The suffering of many sentient beings is due to the way they are treated by other sentient beings, especially sentient beings who determine economic and political policies. To remove the suffering of these victims, the behavior and policies of these other sentient beings will have to change.

\section{The Hermeneutical Privilege of the Poor}

A further difference from Buddhists in the way Christian liberation theologians confront societal greed and seek to bring about structural change has to do with the way they go about analyzing "the causes and conditions" of greed. The "preferential option for the poor" includes what they call the "hermeneutical privilege" or the "epistemological priority" of the poor. With this heavy-duty jargon (many of these theologians began their studies in Europe!) they are declaring that we will not be able to understand, interpret, and adequately analyze the reality of human suffering and its causes unless we listen with the ears and see with the eyes of the oppressed. The experience of victims must be the starting point, the abiding viewpoint, in all efforts to understand structural greed. The suffering of victims bears an "ultimacy" in how we are to understand ourselves and our world. Jon Sobrino puts it powerfully in a recent book when he asks "what is really ultimate for human beings?" His answer: "This 'ultimate' is the suffering of victims. And the 'ultimate' response is compassion toward them, to suffer with them, to live and give one's life in eliminating their suffering." "If we make this "ultimate" our own, it will lead us to truth, to enlightenment. "To allow the suffering (of victims) to speak to us is the necessary condition for knowing all truth." 5 
So for Christians to explore the conditions and causes of structural greed, they will have to do so from the perspective and experience of those who are victims. The assumption here is that the marginalized see things that the privileged, who are willynilly on the side of those in power, cannot see. So the viewpoint and voice of victims must "come first" in our analysis of the causes and conditions of greed. This doesn't mean that theirs is the only voice or that it is infallible. But here is where we listen first, knowing that if we don't do so, our analysis will probably be faulty. When Judith asks whether a "kind of Buddhist 'liberation theology" might develop, I suggest that it could take shape along these lines.

HOPE AND EQUANIMITY-IS THE UNIVERSE JUST MOVING OR

ALSO GOING SOMEWHERE?

The second general issue, focused for me especially by David, has to do with how the conversation between Buddhists and Christians can help us achieve what I think is the necessary balance between active hope and stabilizing equanimity as we confront the greed of our consumerist society. Again, first let me summarize-sketchily and therefore inadequately - two areas where we Christians have to listen attentively to what our Buddhist friends tell us.

\section{What Christian Liberation Theologians Need to Hear from Buddhists}

First, I speak for many of my fellow Christians in admitting how much trouble I have in dealing with what David describes as "the painful burden of our own consumerism." Yes, we are complicit, and that complicity all too easily becomes its own debilitating oppression. We Christians often are not able to have compassion on our own limitations - in this case, our own membership in a consumerist society. Guilt has always been a favored Christian pastime.

Second, hope has all too often, especially among Christian activists, "become a kind of craving"- especially when that hope is much too specified. We know what needs to be done, and when it is not done, we become frustrated, or angry, or even violent (first toward ourselves, then toward others). I squirmed when David Barnhill described "our penchant to live or die by the results of our actions." How often have I personally felt in myself, and seen in my fellow Christians in El Salvador, how "a desire mixed with expectation for things to change for the better in the future... leads us away from the equanimity we need." Our hope-filled activism, our too clear convictions about what the Reign of God requires, have indeed prevented us from "being peace" in our efforts to "make peace." We have much to learn from the Buddhists about equanimity.

But I also have some concerns about possible dangers in the Buddhist emphasis on equanimity. 


\section{Can Equanimity Become Too Individualistic?}

When David Barnhill urges us to be "heartened by the possibility of good work," I fear that those good works remain only individual works_efforts that I undertake in my limited corner of the world, or maybe within the sangha where I meet with like-minded friends. While such efforts would most likely make my immediate environment more equitable and therefore peaceful, I fear that they might end up creating small islands of peace in a sea of greed and injustice. In other words, I don't see how such "good works," in their intent and therefore in their ability, will transform what I stressed earlier: the independently existing structures of greed. Because these structures have an existence of their own, they will not be dismantled simply by good people doing good deeds in their own backyards. Just as we have seen, contrary to what we have heard from high-priest economists, that the wealth created by the globalized market does not automatically "trickle down" to the poor, so too "good works" done by some (or even many) do not automatically "trickle up" to affect the summits of power.

I must admit that I could not follow David Barnhill in grasping how his call to "think little and act spiritually" will truly affect the larger structures of society and the global economy and how such spiritual action will automatically bear material, societal fruits. David seems to urge us to focus only on our immediate context and give up efforts at making any substantive changes in the larger system: “. . . I don't think we will be able to transform the consumer culture at a social level. But we can do a little good, and we can do it in a way that is spiritual work that transforms us, that nourishes and sustains us as we live in such dark times." Even the inspiring description of overcoming at the end of his essay seems to be an overcoming for ourselves in these dark times, not an overcoming that really changes these times and brings light to societal darkness.

What is at issue here is whether it is really possible "to transform the consumer culture at a social level," whether it is really possible to change this world. This brings me to what might be a more fundamental difference between Christians and Buddhists about what we can accomplish in this world.

\section{The Christian Utopian Understanding of History: Things Can Be Different}

The differences that stir uncomfortably, but I think productively, between us are generated by Christian eschatology and its affirmation of history: the world is goingor can go-_somewhere. For Christians (and for the Abrahamic religions in general) there is a purpose and therefore a potential directionality in history-which is not predetermined but will have to be worked out through human-divine cooperation.

So when David Barnhill beautifully states that "we are moved to act by the world's compassion .... This type of action, then, involves a deep sense of being grounded in the cosmos, of acting, we might say, out of the heart of the universe," a Christian would ask whether we can believe that this universe is up to something, whether it's seeking to go somewhere. Or perhaps we can better phrase the intent of this Chris- 
tian question for Buddhists: Is this cosmic compassion seeking to produce cosmic justice?

Liberation theologians would certainly answer "yes," and their assurance is based on their affirmation, and understanding, of utopia: it's a place that we'll never reach, but in trying to do so, we can change the way things are right now. Yes, we remain sinners. Yes, there will always be greed. That's why utopia is ou-topia_- "no place." But the world — not just me and my community_can be less sinful, less greedy tomorrow than it is today. That's why, as Sobrino points out, utopia can also mean eu-topia - the "good place."

Although such hope can itself become an idol, although excessive attachment to it can destroy our equanimity-still, I suspect, that some form of hope that this world can be different is necessary. I say "necessary" not just for me, but especially for the marginalized. "Think little and act spiritually" may be sufficient for me and my middle-class neighbors in Cincinnati, but I'm not sure it is sufficient for the struggling campesinos of El Salvador. They need, also, to think big and act structurally.

Yet, thinking big and acting structurally by itself is dangerous. Such thinking must also be grounded in littleness and equanimity. This is another instance of the "both-and," of the need to balance each other that, for me, has characterized this Buddhist-Christian conversation on greed and our consumerist society. We have some real differences, which means we have some real opportunities to learn from each other and to deepen our shared concern and cooperation for the sufferings of all sentient beings.

NOTES

1. Aloysius Pieris, S.J. God's Reign for God's Poor: A Return to the Jesus Formula (Sri Lanka: Tulana Research Centre, 1998), chapter 4.

2. Jesus the Liberator: A Historical Theological View (Maryknoll:Orbis Books, 1994), pp. $160-162$.

3. Living Buddha Living Christ (New York: Riverhead Books, 1995), pp. 79-81.

4. "Eso 'último' es el sufrimiento de las víctimas. Y la reacción 'última' es la compassion hacia ellas, con-sufrir con ellas y vivir y desvivirse por eliminar su sufrimiento.” Jon Sobrino, S.J. Terremoto, terrorismo, babarie y utopia: El Salvador, Nueva York, Afganistán (San Salvador: UCA Editores, 2003), p. 181.

5. "La necesidad de dejar hablar al sufrimiento [de las victimas] es condición de toda verdad." Ibid., p. 186. This is a quotation from Adorno.

6. Ibid., p. 198. 